\title{
Review \\ Wheat Breeding, Fertilizers, and Pesticides: Do They Contribute to the Increasing Immunogenic Properties of Modern Wheat?
}

\author{
Sayanti Mandal ${ }^{1}$ and Anil K. Verma ${ }^{2, *}$ (i) \\ 1 Institute of Bioinformatics and Biotechnology, Savitribai Phule Pune University, Ganeshkhind Road, \\ Pune 411007, Maharashtra, India; mandalsayanti@gmail.com \\ 2 Celiac Disease Research Laboratory, Department of Pediatrics, Università Politecnica delle Marche, \\ 60123 Ancona, Italy \\ * Correspondence: anilkrvermaa@gmail.com or a.k.verma@pm.univpm.it
}

check for updates

Citation: Mandal, S.; Verma, A.K. Wheat Breeding, Fertilizers, and Pesticides: Do They Contribute to the Increasing Immunogenic Properties of Modern Wheat?. Gastrointest. Disord. 2021, 3, 247-264. https:// doi.org/10.3390/gidisord3040023

Academic Editor: Takuji Tanaka

Received: 20 October 2021

Accepted: 26 November 2021

Published: 1 December 2021

Publisher's Note: MDPI stays neutral with regard to jurisdictional claims in published maps and institutional affiliations.

Copyright: (c) 2021 by the authors. Licensee MDPI, Basel, Switzerland. This article is an open access article distributed under the terms and conditions of the Creative Commons Attribution (CC BY) license (https:/ / creativecommons.org/licenses/by/ $4.0 /)$.

\begin{abstract}
Celiac disease (CD) is a small intestinal inflammatory condition where consumption of gluten induces a T-cell mediated immune response that damages the intestinal mucosa in susceptible individuals. CD affects at least $1 \%$ of the world's population. The increasing prevalence of CD has been reported over the last few decades. However, the reason for this increase is not known so far. Certain factors such as increase in awareness and the development of advanced and highly sensitive diagnostic screening markers are considered significant factors for this increase. Wheat breeding strategies, fertilizers, and pesticides, particularly herbicides, are also thought to have a role in the increasing prevalence. However, less is known about this issue. In this review, we investigated the role of these agronomic practices in depth. Our literature-based results showed that wheat breeding, use of nitrogen-based fertilizers, and herbicides cannot be solely responsible for the increase in celiac prevalence. However, applying nitrogen fertilizers is associated with an increase in gluten in wheat, which increases the risk of developing celiac-specific symptoms in gluten-sensitive individuals. Additionally, clustered regularly interspaced short palindromic repeats (CRISPR) techniques can edit multiple gliadin genes, resulting in a low-immunogenic wheat variety that is safe for such individuals.
\end{abstract}

Keywords: celiac disease; gluten proteins; nitrogen fertilization; glyphosate; genetic modification; CRISPR

\section{Introduction}

Celiac disease (CD) is a small intestinal disorder characterized by partial to total villous atrophy due to the ingestion of a storage wheat protein 'gluten' in genetically susceptible individuals. Human leukocyte antigen (HLA) -DQ2 and -DQ8 alleles is considered the main risk factor for the development of CD [1]. Gluten peptides contain epitopes that trigger CD. Complete exclusion of gluten from the diet is the only treatment so far. CD is predominant globally with an overall prevalence of $1 \%$ in the general population [2]. However, there is a variation in the prevalence country-wide. CD predominantly occurs in Europe. Nonetheless, country-wide variation has been reported. A lower prevalence has been estimated in Germany $(0.2 \%)$ whereas a higher prevalence has been estimated in Finland (2.4\%) and Sweden (2.6\%) [3,4]. In recent decades, multiple studies suggested an increased prevalence. In the latest study, Gatti et al. showed an increased prevalence in the pediatric population. The authors also showed an increasing pattern in prevalence over 25 years. The authors conducted two studies during the 1990s and estimated $0.39 \%$ and $0.54 \%$ prevalence. After 25 years they found an eight-fold rise in the prevalence, i.e., $1.6 \%$ [5]. Earlier to this, the authors confirmed a five-fold increased prevalence in the Unites States between 1974 and 2001 [6]. Thus far, a definite factor for this rise in prevalence is unknown. However, these are certain postulations provided by some studies. Increasing awareness of CD among the medical practitioners and general population and 
several landmark screening studies in different countries are considered significant factors. Apart from this, the development of advanced and highly sensitive diagnostic screening markers are also supposed to have a substantial role. During the 1980s, the first-line CD screening serological marker, i.e., IgA class anti-gliadin antibody test (AGA) had sensitivity between 60.0 and $96 \%$, whereas the current first-line screening sero-marker, i.e., IgA class tissue transglutaminase (tTG) has sensitivity up to 100\% [7]. Verma et al. showed that the increased accuracy of IgA anti tTG ab test in comparison to IgA AGA significantly contributes to the observed increase in the prevalence [8]. Nonetheless, none of these factors may be solely responsible for the increasing prevalence but combinations of these factors may be.

The average wheat consumption per capita was $66 \mathrm{~kg}$ until 2004-2018. In the last 60 years, wheat consumption has increased. especially in Asia (1.87-fold) and Africa (1.58-fold) [9]. This increased consumption of wheat over the years has been correlated with the increased prevalence of CD $[10,11]$. However, in a very important study, Lionetti et al. found no significant correlation between the CD prevalence and the level of wheat consumption. This study found a highly significant correlation between wheat consumption and the frequency of HLA-DQ2/8 alleles [11]. It is widely known that $30-50 \%$ of the healthy population display HLA-DQ alleles and 3-5\% develop CD $[1,5,11]$. Hence, consumption of wheat is associated with the risk of CD development at least in at-risk populations. In recent years, multiple studies gave evidence that to fulfill the wheat demand wheat production was increased $[12,13]$. Nonetheless, due to this quality of wheat was also improved. To improve the wheat quality, the amount of gluten in wheat has also been increased. This increased amount of gluten, due to specific immunogenic epitopes, stimulates celiac-specific immunological reactions. Consumption of such wheat increased the risk of developing CD, especially in genetically predisposed individuals.

Accumulating evidence shows that agronomical practices such as classical plant breeding, use of nitrogen $(\mathrm{N})$ fertilizers, and pesticides might play a role in increasing the amount of the grain storage protein (GSP), i.e., gluten. However, there is only a limited amount of information accessible on this problem.

This review updates the current knowledge of different agricultural practices that could be related to a potential increase in gluten amount in wheat that might influence the CD prevalence. This article also discusses different approaches to eliminate/reduce the toxic gliadin content of wheat and makes it suitable for consumption the individuals having gluten sensitivity.

\section{Wheat Breeding Strategies: Current Challenges}

Traditional breeding techniques (single-seed, pedigree, backcross method, recurrent selection, and pure line selection) were primarily based on crosses and phenotypic selection. These methods have been widely applied techniques around the globe for more than a century. These methods still account for the production of the diverse number of cultivars. Yield improvement, and stability of grain, that increases the biomass, are two primary goals of a wheat breeding. To improve the cultivar production, traditional breeding methods were remained successful in increasing the yield and quality of wheat [14-16]. These techniques, with a few modifications, can be used to improve the effectiveness of crop breeding reduce the breeding duration. This approach may also increase the frequency of favorable genotypes in a population, it may not be effective for traits with low heritability.

Traditional methods take approximately $9-12$ years to complete a breeding process; however, this long breeding duration can be substantially shortened by using the Marker Assisted Selection (MAS) process [17]. However, as with breeding techniques, MAS is also an expensive [18] plant breeding process.

\section{Modern Wheat Cultivars Have a Greater Immunostimulatory Capacity, Linked with Better Seed Quality}

In recent years, it has been claimed that extensive breeding results in contemporary wheat cultivars having lower levels of health-promoting components [19-23]. Several 
researchers have recently looked into the other nutritive components of wheat, such as dietary fiber (DF), which has several health advantages such as maintaining healthy gut microbiota and obesity mitigation; they found that intensive breeding does not reduce DF in current cultivars compared to the older genotype [15]. It was also found that the overall arabinoxylan content does not vary between current and ancient genotypes in whole meal or semolina whereas contemporary cultivars have a greater percentage of soluble arabinoxyl in whole meals and beta-glycan in semolina compared to the old genotypes [15].

These finding suggest that the breeding process led to additional improvements in the nutritional properties of wheat. Apart from its nutritional value, wheat protein may trigger inflammatory immune reactions and disorders such as wheat allergies, CD, non-celiac gluten sensitivity (NCGS), fructose malabsorption, and irritable bowel syndrome (IBS), highlighting the need for less-reactive wheat products that can help improve the overall quality of life [24,25].

Wheat proteins, including non-gluten proteins, i.e., amylase/trypsin inhibitors (ATI), have been identified as triggering factors in the CD development. Recent comparative investigations of the nutritional properties of ancient and modern wheat genotypes confirmed that breeding enhances the gluten quality of wheat, both in terms of its technical performance in creating high-quality baking products and its allergenic potential [19] (Figure 1). More precisely, a greater gluten index has been observed in contemporary cultivars associated with increased gluten content. The breeding process also contributed to a dramatic reduction in wheat-dependent exercise-induced anaphylaxis (WDEIA) of a significant allergen, whereas the ancient and modern cultivars were similar in their $\alpha$ and $\beta$-type gliadin content and the former was a factor associated with CD toxicity [19]. However, despite the presence of allergens in wheat grains, there is a vast genetic diversity within the wheat germplasm, and further research is required to develop cultivars with reduced reactivity and/or greater secondary health-promoting components suitable for consumption $[20,24]$. This opens up an opportunity for fertilization that has an impact on the yield and quality of wheat production, especially fertilization with nitrogen.

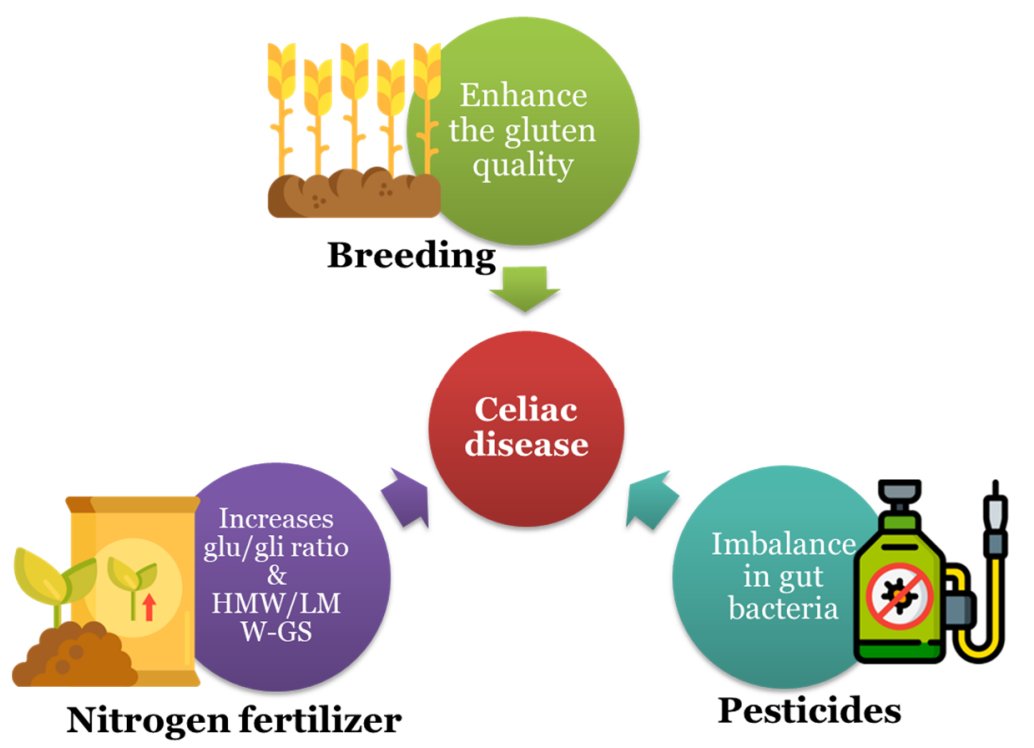

Figure 1. Wheat breeding, nitrogen $(\mathrm{N})$ fertilizers, and pesticides (glyphosate), various agronomical practices that contributes to the increasing prevalence of celiac disease (CD).

\section{Nitrogen Fertilizers: Substantially Affects Grain Yield and Glutenin Protein}

Nitrogen is an important macronutrient necessary for plant growth and development. It requires for the protein and starch production, both have an impact on grain yield and quality. The quantity and timing of $\mathrm{N}$ fertilizer application have a significant impact on wheat production and quality. In general, high-N fertilizer treatment improves 
endosperm protein body, storage protein content, and flour-processing quality through changing the expression levels of genes encoding components of protein biosynthesis pathways. Moreover, the use of $\mathrm{N}$ fertilizer significantly increases the ratios of glutenin to gliadin (glu/gli) and high molecular weight glutenin subunits (HMW-GS) to low molecular weight glutenin subunits (LMW-GS) that results in improved wheat quality for end-use (Figure 1) $[26,27]$. Various recent studies indicate that $\mathrm{N}$ fertilizer usage increases various components of wheat storage protein (prolamins), making consumption difficult for gluten-sensitive individuals. Table 1. summarizes the findings of these investigations.

Table 1. Recent studies demonstrating the access use of nitrogen $(\mathrm{N})$ fertilizers increases different components of wheat storage protein.

\begin{tabular}{|c|c|c|c|c|}
\hline S. No & Genotype & Effect of Nitrogen Application & Year & Reference \\
\hline 1. & Triticum aestivum L. cv. Neepawa & $\begin{array}{l}\text { Proteins and gliadins increased in } \\
\text { the flour }\end{array}$ & 2000 & [28] \\
\hline 2. & T. aestivum L. cv. Astella (Winter wheat) & $\begin{array}{l}\text { Increase in wet gluten concentrations and } \\
\text { total protein }\end{array}$ & 2004 & [29] \\
\hline 3. & T. aestivum L. cv. Soissons (Winter wheat) & $\begin{array}{l}\text { Gliadins, LMW-GS, and HMW-GS levels } \\
\text { increase significantly }\end{array}$ & 2004 & [30] \\
\hline 4. & $\begin{array}{l}\text { T. aestivum L. cv. Marija, Žitarka, Srpanjka, } \\
\text { Soissons, Renan and Kuna }\end{array}$ & $\begin{array}{l}\text { Gluten content increased in the } \\
\text { wheat grain }\end{array}$ & 2007 & [31] \\
\hline 5. & T. aestivum L. Kargo (Spring triticale) & Highest significant amount of wet gluten & 2009 & [32] \\
\hline 6. & T. aestivum L. cv. Zebra (Spring triticale) & Increase in grain yield and gluten content & 2009 & [33] \\
\hline 7. & T. aestivum L. cv. Privileg (winter wheat) & $\begin{array}{l}\omega \text {-gliadins and HMW glutenin were } \\
\text { increased by high levels of } N\end{array}$ & 2009 & {$[34]$} \\
\hline 8. & $\begin{array}{l}\text { T. aestivum L. cv. Trijumf and Favorit } \\
\text { (winter triticale) }\end{array}$ & Wet gluten content increased & 2010 & [35] \\
\hline 9. & T. aestivum L. cv. Soissons (Winter wheat) & $\begin{array}{l}\text { Increase in the HMW glutenin subunits } \\
\text { (HMW-GS) }\end{array}$ & 2010 & [36] \\
\hline 10. & $\begin{array}{l}\text { T. aestivum L. cv. Cordiale, Hereward, } \\
\text { Istabraq, Malacca, Marksman and Xi } 19\end{array}$ & $\gamma$-gliadin gene expression increased & 2012 & [37] \\
\hline 11. & T. aestivum L. cv. Cezanne & $\begin{array}{l}\text { Improves grain yield, quality as well } \\
\text { gliadin and gliadin/protein ratio }\end{array}$ & 2013 & [38] \\
\hline 12. & T. aestivum L. cv. Andrus (Spring triticale) & $\begin{array}{l}\text { Increase in albumins with globulins and } \\
\omega \text { and } \alpha / \beta \text { prolamins in grain }\end{array}$ & 2013 & [39] \\
\hline 13. & $\begin{array}{l}\text { T. aestivum L. cv. Cordiale, Hereward, } \\
\text { Istabraq, Malacca, Marksman and Xi } 19\end{array}$ & $\begin{array}{l}\text { increased accumulation of } \omega-5 \text { and } \\
\qquad \omega-2 \text { gliadins }\end{array}$ & 2014 & [40] \\
\hline 14. & T. aestivum L. cv. Quartzo & $\begin{array}{l}\text { Increasing kernel protein content and } \\
\text { gluten content of the flour }\end{array}$ & 2015 & [41] \\
\hline 15. & T. aestivum L. cv. Tybalt (spring wheat) & Increase in gluten content & 2016 & [42] \\
\hline 16. & $\begin{array}{l}\text { T. turgidum L. subsp. durum (Desf.) } \\
\text { Husn., cv. Achille }\end{array}$ & $\begin{array}{l}\text { Increase in GPC, total gluten, and } \\
\text { gluten fractions }\end{array}$ & 2016 & [43] \\
\hline 17. & T. aestivum L. cv. Zhongmai 175 & $\begin{array}{l}\text { High-nitrogen fertilizer enhanced grain } \\
\text { protein and gluten contents }\end{array}$ & 2016 & [44] \\
\hline 18. & T. aestivum L. cv. Tobak and JB Asano & $\begin{array}{l}\text { Enhances GPC and the relative } \\
\text { abundance of HMW-GS }\end{array}$ & 2016 & [45] \\
\hline 19. & $\begin{array}{l}\text { T. aestivum L. cv. Shumai } 969 \text { (SM969), } \\
\text { Shumai } 482 \text { (SM482), Chuannong 16 } \\
\text { (CN16) and Mianmai } 51 \text { (MM51) }\end{array}$ & $\begin{array}{l}\text { HMW-GSs and } \omega \text {-gliadin, greatly } \\
\text { responded to increased nitrogen }\end{array}$ & 2018 & [46] \\
\hline 20. & T. aestivum L. cv. Skagen & Higher average gluten content in grain & 2018 & [47] \\
\hline
\end{tabular}


Table 1. Cont

\begin{tabular}{|c|c|c|c|c|}
\hline S. No & Genotype & Effect of Nitrogen Application & Year & Reference \\
\hline 21. & T. aestivum L. (Korean wheat cultivars) & $\begin{array}{c}\text { Increases in gluten concentrations in flour, } \\
\alpha+\beta \text {-gliadin and decreases in } \omega \text { and } \\
\gamma \text {-gliadin concentrations }\end{array}$ & 2018 & [48] \\
\hline 22. & T. aestivum ssp. Spelta & $\begin{array}{l}\text { Increase in } \alpha \text {-gliadin epitopes related } \\
\text { to } C D\end{array}$ & 2018 & [49] \\
\hline 23. & T. aestivum L. cv. Ingenio and Marcopolo & $\begin{array}{l}\text { Increase in total gluten proteins (gliadins } \\
\text { and glutenins) }\end{array}$ & 2018 & [50] \\
\hline 24. & T. aestivum L. cv. Tybalt (spring wheat) & Increase in gluten content & 2018 & [51] \\
\hline 25. & T. aestivum L. cv. Tobak and JB Asano & $\begin{array}{l}\text { Increase in globulins, LMW-GS, } \alpha-\text {, } \\
\text { and } \gamma \text {-gliadins }\end{array}$ & 2019 & [52] \\
\hline 26. & T. aestivum L. (Winter wheat) & $\begin{array}{l}\text { Gluten content was } \\
\text { significantly increasing }\end{array}$ & 2020 & [53] \\
\hline 27. & $\begin{array}{l}\text { T. aestioum L. Zhongmai } 175 \text { (Chinese } \\
\text { winter wheat) }\end{array}$ & $\begin{array}{l}\text { Increases in gluten, total gliadin, and } \\
\text { glutenin content }\end{array}$ & 2020 & [54] \\
\hline 28. & $\begin{array}{l}\text { T. aestivum L. cv. Xinong 1718, Fa } 710 \text { and } \\
\text { Fa } 790 \text { (NILs) }\end{array}$ & $\begin{array}{l}\text { Increased the accumulation of total } \\
\text { protein, glutenin, glu/gli ratio, } \\
\text { HMW /LMW-GS, and GMP }\end{array}$ & 2020 & [55] \\
\hline
\end{tabular}

LMW-GS, Low molecular weight glutenin subunits; HMW-GS, high molecular weight glutenin subunits; GPC, grain protein concentration; GMP, glutenin macropolymer; CD, celiac disease; NILs, near-isogenic lines.

Daniel and Triboi reported that the gliadin composition was altered as a result of increased temperature and the application of $\mathrm{N}$ fertilizer to the growing wheat crop. As a result of the $\mathrm{N}$ fertilizer, an increase in the grain protein content was observed from 3.4 to $6.8 \mathrm{mg}$, and which in turn, increased the gliadins fraction of the total proteins from $23 \%$ to $29 \%$. According to the findings, application of $\mathrm{N}$ fertilizers further positively changed the proportions of the gliadins fraction, i.e., $\omega: 10-19 \%, \alpha+\beta: 42-58 \%$ and $\gamma: 24.5-32 \%$. This led to the conclusion that an increase in $\mathrm{N}$ availability enhances the synthesis of $\omega$-gliadins, perhaps due to their high glutamine content [28]. Furthermore, $\mathrm{N}$ topdressing also resulted in a statistically significant increase in grain production ranging from +0.35 to $+0.82 \mathrm{t} / \mathrm{ha}$ (ton/hectares), which had a positive effect on wet gluten content and crude protein formation [29]. Pepo et al. 2005 successfully demonstrated that use of $\mathrm{N}$ fertilization shows a considerable increase in wet gluten content in the winter wheat [56]. Tea et al. (2004) showed that the amount and composition of storage proteins, as well as dough mixing characteristics, are greatly influenced by $\mathrm{N}$ supplied through foliar spray, and that $\mathrm{N}$ fertilization enhances all storage proteins (gliadins, LMW-GS, HMW-GS) [30]. Application of high amount of $\mathrm{N}$ fertilizers improved the bread-making quality but it also significantly increases the wet gluten by $40 \%$ as indicated by Varga B. and colleagues [31] Similar results showed by Knapowski et al. (2008) where wet gluten content increased by $25 \%$ when $\mathrm{N}$ fertilizer was supplied through the soil along with foliar application $[32,33]$. Quantitative proteome analysis by Zörb and Grover [34] revealed that high N fertilizers trigger the glutenin concentration in comparison to the gliadin fraction in winter wheat $\mathrm{cv}$. Privileg. Thus, greater rates of splitting $\mathrm{N}$ fertilization resulted in a higher accumulation of gliadins and glutenins in wheat grain.

The addition of $\mathrm{N}$ fertilizers results in an increase in the concentration of HMWGS, allowing for a greater degree of disulfide bond formation and, as a result, improves breadmaking quality [36]. Wan et al. (2012) effectively demonstrated that the expression of $\gamma$-gliadin genes in growing wheat grains is strongly controlled by $\mathrm{N}$ availability [37]. The findings of Mendizabal et al. showed that ammonium $\left(\mathrm{NH}_{3}\right)$ enhanced both kinds of grain reserve proteins (gliadins and glutenins), as well as the ratio of gli/glu ratio with nitrate nutrition. Gliadin content in the flour was increased by $38 \%$ when ammonium nutrition was applied. The increase in gliadin content was directly related to the improvement in grain 
$\mathrm{N}$ content and protein ratio. After applying ammonium nutrition to wheat, the amount of gliadin found in the flour rose by $38 \%$ and the gliadin/protein ratio also increased by $18 \%$ [38].

In 2013, Wojtkowiak et al. indicated that increasing the $\mathrm{N}$ dosage resulted in an increase in albumins, globulins, and $\omega$ - and $\alpha / \beta$ gliadins in grain [39]. It was further determined by Wan et al. that increasing the amount of $\mathrm{N}$ fertilizer applied to field plots resulted in higher expression of $\omega$-gliadin transcripts and higher proportions of $\omega$-5 gliadins. However, when the starchy endosperm was exposed to high $\mathrm{N}$ levels, the spatial patterns of $\omega$-gliadin production and deposition were differentially increased. The significant rise in polymeric $\omega-5$ gliadin may increase total glutenin polymers, which are also the primary components responsible for causing the most common kind of WDEIA [40]. Glutenin synthesis was considerably more effective as a result of the higher $\mathrm{N}$ dosage, which led to a higher glu/gli ratio. This is consistent with previous findings that various gluten gene families expressed differently as a result of $\mathrm{N}$ fertilizers and $\mathrm{N}$ deficiency [43]. Grain protein and gluten content, which are important rapid visco analyser (RVA) characteristics linked to many properties of starch, such as viscosity, and softening degree, were substantially enhanced by high-N fertilizer application. Gln, Gly, Pro, and Glu are the major components of glutenin subunits that determine dough viscosity and elasticity. The use of high-N fertilizers hastened the accumulation of these $\mathrm{N}$-containing amino acids, increasing the amount of storage protein [44]. As a result of the $\mathrm{N}$ splitting impact on the proportions of gliadins and glutenins (\% total protein) and the relative abundance of specific HMW-GS, this indicated that $\mathrm{N}$ application at the late boot stage increased loaf volume of wheat flour [45]. The use of $\mathrm{N}$ has a positive impact on GSPs and their portion in wheat four. Altogether, $\mathrm{N}$ had the greatest impact on HMW-GSs and GSPs, maybe the cause of the significant rise in the ratio of HMW-GSs to LMW-GS, which resulted in a significant difference in the quality of wheat processing [46]. Results were also observed in Tobak cultivars where LMW-GS, two $\alpha$-gliadins, and one $\gamma$-gliadin were increased by split $\mathrm{N}$ application [52]. Furthermore, increasing dosages of $\mathrm{N}$ applications, as well as higher split dose applications, substantially impacted the gluten content [53]. In this study, RP-UPLC and 2D-DIGE analyses of the gliadin and glutenin subproteomes revealed that applying a large amount of high-N fertilizer $\left(240 \mathrm{~kg} \mathrm{ha}^{-1}\right)$ significantly increased the accumulation of gliadin and glutenin components as well as the contents of storage proteins, implying improved dough viscoelasticity and bread quality [54]. The addition of N, expedited and enhanced the accumulation of total protein, glutenin, glu/gli ratio, HMW/LMW-GS, and GMP in the grain, raised the disulfide bond concentration, upgraded the secondary and microstructure of the gluten, and improved the thermal stability and dough mixing characteristics [55]. In recent decades, $\mathrm{N}$ fertilization of cereal crops has risen, having a significant impact on the amount and quality of storage proteins (gliadins and glutenins) and improved bread-making quality. However, this makes wheat consumption a challenge for patients with CD. Nonetheless, pesticides such as herbicides, which have been used widely along with fertilizer to boost agricultural yields, are required to meet the world's growing food demand.

\section{Glyphosate-Based Herbicides (GBHs): Role in Modern Agriculture}

Presently, glyphosate-based herbicides (GBHs), are the most extensively used herbicides. In GBHs, glyphosate is the primary active component, which is widely used for agronomic purposes, including weed control and crop desiccation. Approximately 140,000 tons of glyphosate is used annually, which is often found in products such as Roundup (commercial name of a commonly used herbicide) [57]. Desiccation of crops, particularly wheat, is one agricultural technique that gained favor in the 1990s and continues till today. Desiccation is the procedure of applying a chemical herbicide to a plant before harvesting it to destroy any growth on the plant so that the crop dries up more rapidly and uniformly as a result of environmental conditions (dry-down). In areas where the growing season is short and damp, desiccation tends to compensate for uneven growth. 
Cereal grains, especially wheat, are particularly susceptible to irregular ripening, which results in a higher frequency of desiccation than other cereals [58,59]. Glyphosate is a major herbicide, as it has high efficacy, low cost, and a broad spectrum of action, generally formulated to control both broadleaf and grass weeds.

\section{Glyphosate: As a Potent Herbicide Associated with Increasing Incidence of CD}

A broad-spectrum herbicide, such as glyphosate, dissected crops over a period of weeks. Glyphosate, has the additional advantage of suppressing green weeds, making it one of the most widely used commercial desiccants. It is important to also highlight that wheat as a crop, along with beans, maize, and soybeans has significant levels of glyphosate residue as a result of its application in desiccation. Although eliminating wheat from one's diet does not guarantee the elimination of glyphosate exposure. The agricultural practices we have embraced in the past two decades are responsible for this dramatic increase in wheat sensitivity to gluten intolerant patients.

The human gastrointestinal tract is home to billions of microorganisms. A large proportion of these bacteria are known as "good gut bacteria" and play important roles including helping the body fight infections by regulating the immune responses, energy gathering, and producing vitamins, among others [60]. Glyphosate and its major metabolite, aminomethylphosphonic acid (AMPA), have the ability to produce dysbiosis by establishing an imbalance between commensal and opportunistic pathogens in the gut microbiome [61,62]. A shortage of beneficial bacteria or gut flora may lead to a variety of gastrointestinal disorders, including CD, peritonitis, and bacterial diarrhea [63]. In the human gastrointestinal tract, there are approximately 400 different bacteria species and the majority of which are anaerobic. Gut intestinal flora is critical for several bodily processes, including providing energy, preventing pathogen attack, maintaining immunity, and metabolizing certain vitamins, including biotin, K, B12, folic acid, and thiamine $[60,63]$. Various physiological consequences may occur if gut bacteria are decreased or disturbed in some manner, leading to gastrointestinal disorders.

$\mathrm{CD}$ is linked with a decrease in the number of commensal bacteria such as Lactobacilli and Bifidobacteria (Gram-positive, lactic acid-producing bacteria) in the gut, which are known to be preferentially destroyed by glyphosate, as well as an increase in Clostridium difficile, which is known to be promoted by glyphosate exposure [64-66] (Figure 1). Recently, attempts have been made to create gluten-containing foods that are safer for ingestion by celiac patients by making use of the ability of Bifidobacteria and Lactobacilli to modify gluten $[67,68]$.

Researchers have discovered that excessive glyphosate exposure causes dysbiosis, which increases the frequency of opportunistic pathogens, particularly those belonging to the phylum Fusobacteria [69]. Increased amounts of other bacterial species, such as Prevotella spp. and Actinomyces spp., have also been linked to high-dose glyphosate herbicide exposure [70]. The presence of an increased number of rod-shaped bacteria such as Prevotella spp. and Actinomyces spp., has been identified as a possible risk factor for the development of $\mathrm{CD}[71,72]$. These results indicate that glyphosate exposure at high doses may increase the development of opportunistic pathogens in the gut microbiome. Glyphosate-induced dysbiosis appears to favor several disease phenotypes, including inflammation, reflux disease, obesity, and colon cancer, and maybe a key environmental trigger in the etiology of CD due to changes in gluten-neutralizing bacteria or an overabundance of rod-shaped bacteria.

Indeed, Rothia genus subspecies have been discovered as being important in the digestion of gluten in the mouth and upper gastrointestinal system [73]. Gluten proteins are tough for human proteolytic enzymes to digest, and recent research shows that microorganism-derived enzymes helps in the breakdown of these proteins. In addition to having the enzymes necessary for gluten protein breakdown, Rothia spp. also have enzymes that target immunogenic epitopes associated with $C D$ [73]. These results indicate that exposure to previously proven safe levels of glyphosate may lead to drastic alterations in the microbiome and that it may be an environmental trigger in the development of CD. 
Although in many diseases, such as CD and inflammatory bowel disease (IBD), the etiology involves a mix of environmental and biological variables.

Inflammation, reflux disease, obesity, and colon cancer are among phenotypes that seem to be favored by glyphosate dysbiosis. It has also been proven that glyphosate is a significant environmental trigger in the genesis of $C D$, either via changes in gluten neutralizing bacteria or an overabundance of rod-shaped bacteria [69-72,74-76].

\section{Methods to Reduce the Immunogenic Properties of Modern Wheat}

Wheat production and grain-use characteristics have continued to improve as a result of classical and molecular breeding, fertilizers, and pesticide usage, but it also makes it difficult for celiac patients to consume wheat. Multiple studies demonstrated that gliadin accumulation may decrease without compromising the end-use quality of wheat, and many gluten proteins do not contain the known wheat-sensitivity-related epitopes and this is encouraging. As a result, alternative techniques and methods should be applied to create genetically engineered lines with lower gluten content [77]. The four important approaches (brief overview) for enhancing wheat grain by removing or modifying the toxic gluten proteins have been discussed in the following sections and a summary is given in Table 2. 
Table 2. Recent studies showing the methods to eliminate or reduce gliadins content of different Triticum aestivum variety.

\begin{tabular}{|c|c|c|c|c|}
\hline S. No. & Cultivar/Transgenic Lines & Target Gene & Output & References \\
\hline & & RNA & & \\
\hline
\end{tabular}

1. Triticum aestivum cv. Chinese Spring; T. aestivum cv. Butte 86

$\omega-1,2$ gliadins

$\omega-1,2$ gliadins were effectively silenced and one transgenic line showed improved dough functionality. This reduced the immunogenicity of flour protein to antibodies from CD patients.

Multiple secalins and closely related $\omega$-gliadins showed substantial reductions; HMW-GSs and $\alpha$-gliadins were elevated; and dough functioning for two transgenic lines

was improved.

2.

T. aestivum cv. Bobwhite (BW)

Secalins in 1BL/1RS wheat line are many lines that lack CD epitopes and therefore are much less immunogenic due to the absence of $\alpha$ - and $\omega$-gliadins and overall protein and starch contents of the grains are unaltered

3.

T. aestivum cv. Bobwhite 208 (BW208)

$\alpha-, \gamma$ - and $\omega$-gliadins, LMW-GSs in the transgenic lines

In one line, the content of $\omega-5$ gliadin was reduced by $80 \%$,

while in another line, it was completely removed. WDEIA patients' responsiveness to the IgE antibody was significantly decreased; enhancing the characteristics of dough functioning.

In two transgenic lines, the content of $\alpha$-gliadin was significantly decreased, but this was accounted for by higher amounts of $\gamma$ - and $\omega$-gliadins, HMW-GSs, and other grain proteins; no substantial impact on flour functioning

$$
\text { was found. }
$$

Strongly reduced gliadin expression by $85.6 \%$; transgenic wheat lines with extremely low toxicity for $\mathrm{CD}$ patients produced; and several of the transgenic lines demonstrated enhanced end-use quality and nutritional value.

Increased levels of $\alpha$ - and $\omega$-gliadins together with decreased

$[89,90]$
T. aestivum cv. Bobwhite 208 (BW208), Lines A1152, A1158, A1406, C655, C657, D445, D623, C217 and D598 expression of $\gamma$-gliadins in nine transgenic lines, six transgenic

lines exhibited increased SDS-sedimentation values.

$\gamma$-Gliadins 
Table 2. Cont.

\begin{tabular}{|c|c|c|c|c|}
\hline S. No. & Cultivar/Transgenic Lines & Target Gene & Output & References \\
\hline \multicolumn{5}{|c|}{ Overexpressing transgenics lines } \\
\hline 8. & T. aestivum cv. Brundage 96 & $\alpha$-Gliadins & $\begin{array}{l}\text { Transgenic wheat expressing engineered glutenase, which } \\
\text { were capable of degrading the CD epitopes carried by } \\
\alpha \text {-gliadins under simulated gastrointestinal condition }\end{array}$ & [91] \\
\hline \multicolumn{5}{|c|}{ Deletion wheat lines } \\
\hline 9. & $\begin{array}{c}\text { Xiaoyan 81, Xy81, DLGliD2, Zhengmai } 366 \\
\text { and ZDLGliD2. }\end{array}$ & $\alpha$-Gliadins & $\begin{array}{l}\text { Six deletion lines deficient in the gliadin chromosomal loci } \\
\text { were developed; the line lacking Gli-D2 demonstrated better } \\
\text { dough functioning and breadmaking quality, with a } \\
\text { substantial reduction in the number of CD epitopes. }\end{array}$ & {$[92,93]$} \\
\hline 10. & T. aestivum cv. Pegaso (bread wheat) & $\alpha$-Gliadins & $\begin{array}{l}\text { Three deletion lines lacking Gli-A2, Gli-D2, or Gli-A2/Gli-D2 } \\
\text { were created; significant reductions in } \alpha \text {-gliadin expression } \\
\text { were found in all three lines; the 33-mer peptide containing } \\
\text { gliadins was not identified in the lines lacking Gli-D2 } \\
\text { or Gli-A2/Gli-D2. }\end{array}$ & [94] \\
\hline 11. & $\begin{array}{l}\text { T. aestivum } 39 \mathrm{~N} \text {, winter wheat (contained } \\
\text { inactive genes in } \omega \text {-gliadin loci that code } \\
\text { no proteins) }\end{array}$ & $\omega-1,2$ and $\omega-5$ gliadins & $\begin{array}{l}\text { Gliadin immunoreactivity was reduced by around } 30 \% \text { in } \\
\text { wheat genotypes missing both } \omega-1,2 \text { and } \omega-5 \text { gliadins, while } \\
\text { gluten functioning was enhanced. }\end{array}$ & [95] \\
\hline 12. & $\begin{array}{c}\text { Hybrid wheat (spelt wheat, cultivar } \\
\text { Oberkummler Rotkorn and Polish high quality } \\
\text { wheat line LAD 480) }\end{array}$ & $\alpha-, \gamma-$ and $\omega$-gliadins & $\begin{array}{l}\text { Three deletion lines were generated, each with a null allele at } \\
\text { Gli-D1, Gli-B1, or Gli-B2; immunoreactivity of flour proteins } \\
\text { was decreased by } 6-18 \% \text { in the deletion lines. }\end{array}$ & [96] \\
\hline \multicolumn{5}{|c|}{ Genome editing through CRISPR/Cas9 } \\
\hline 13. & $\begin{array}{c}\text { T. aestivum cv. Fielder; T. aestivum cv. BW208 } \\
\text { and THA53 (bread wheat), and T. aestivum, cv } \\
\text { Don Pedro (DP, durum wheat) }\end{array}$ & $\alpha$-Gliadins & $\begin{array}{l}\text { Using CRISPR/Cas9 genome editing, simultaneous mutation } \\
\text { of several } \alpha \text {-gliadin genes was used to successfully lower the } \\
\text { level of immunoreactivity for gluten proteins by up to } 85 \% \text {. }\end{array}$ & {$[97,98]$} \\
\hline
\end{tabular}

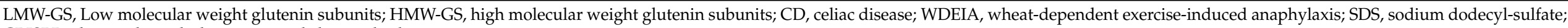

CRISPR, clustered regularly interspaced short palindromic repeats. 


\subsection{RNA Interference (RNAi)-Based Gene Silencing in Wheat}

The first strategy is to employ RNA interference (RNAi)-mediated silencing of all or certain gliadins to develop a transgenic wheat lines [84-90,99]. Overall, the gliadin-silenced lines had reduced gliadin content and immunogenic potential, as well as demonstrated better end-use quality metrics. RNAi constructs, such as those developed by Barro et al. were used to simultaneously silence the expression of $\alpha-, \gamma$ - and $\omega$-gliadins using combinations of RNAi constructs, which eliminated CD epitopes from the highly immunogenic $\alpha$ and $\omega$-gliadins while not affecting the total protein and starch contents of the grains [81]. Additionally, RNAi was effectively utilized to suppress the production of $\omega-5$ gliadins; the resulting lines showed enhanced flour qualities and may help reduce the occurrence of WDEIA $[78,79,82,83]$. Altenbach et al. recently showed that RNAi could be used to lower the expression of $\omega-1,2$ gliadins by a considerable amount, with the resultant lines exhibiting considerably reduced immunogenic potential and dramatically better end-user quality metrics $[100,101]$. With the use of RNAi, it is possible to suppress the rye secalins that are produced in the wheat background due to the presence of the 1BL/1RS translocation chromosome and these transgenic lines demonstrated improved dough functional characteristics and rheological properties [80,102,103]. Finally, Gil-Humanes et al. discovered that the low-gliadin transgenic wheat lines created via RNAi had better nutritional quality due to increased lysine content in the grains [88]. Garca Molina et al. reported that consumption of bread produced with low-gliadin wheat (E82) flour, which contained 98.1\% less gluten when tested with the R5 antibody, resulted in beneficial alterations in the composition of the gut microbiota of NCWS patients [104].

\subsection{Developing Overexpressing Transgenic Wheat}

The second strategy is to create transgenic wheat lines that produce modified "glutenases" for the targeted intestinal breakdown of celiac causing epitopes. Osorio et al. (2019) created transgenic wheat lines with endosperm specific expression of barley endoprotease B2 (EP-HvB2), Flavobacterium meningosepticum prolyl endopeptidase (PE-FmPep), and Pyrococcus furiosus prolyl endopeptidase (PE-PfuPep) [91]. The end-use quality of four of these preconditioned gluten detoxifiers (EP-HvB2 + PE-FmPep or EP-HvB2 + PE-PfuPep) was not affected, but the CD epitopes included in the 33-mer gliadin peptide were degraded under simulated gastrointestinal circumstances. Transgenic lines showed a $72 \%$ decrease in immunogenic peptides, paving the way for the development of an intracellular enzyme treatment for $\mathrm{CD}$ without compromising wheat overall agronomic performance [91].

\subsection{Wheat Deletion Lines}

In the third strategy, wheat deletion lines that are deficient in one or more gliadin chromosomal sites are developed. Gliadin deletion lines with null alleles at Gli-D1, Gli-B1, or Gli-B2 were generated and evaluated by Waga et al., who observed that immunoreactivity of four proteins in the deletion lines was lowered by $6-18 \%$ than that compared to the wild-type control (WT) [96]. Following that, wheat genotypes lacking both $\omega-1,2$ and $\omega-5$ gliadins were created, which resulted in a 30\% reduction in gliadin immunoreactivity while improving gluten content [95]. On the other hand, Camerlengo et al. (2017) reported three wheat deletion lines that were deficient in Gli-A2, Gli-D2, and Gli-A2/Gli-D2, respectively to the WT. These mutant lines showed significant reductions in $\alpha$-gliadin expression, with the 33-mer peptide-carrying gliadins not identified in the ones lacking Gli-D2 or Gli-A2/Gli$D 2$ [94]. Wang et al. created six wheat deletion lines, each deficient in one of the six gliadin chromosomal locations. The DLGliD2 line, which had Gli-D2 deleted, demonstrated better breadmaking quality and dough functionality, with the number of $C D$ epitopes being substantially reduced in comparison to the control line [92,93]. Moreover, these deletion lines are non-transgenic, they may be utilized directly in the development of wheat lines that are less toxic to those who suffer from CD. 


\subsection{Genome Editing through CRISPR}

The fourth strategy involves utilizing genome editing to alter gluten gene expression. Numerous genome (gene) editing strategies have been developed. However, the discovery of clustered regularly interspaced short palindromic repeats (CRISPR), which offer simple and ease of targeted gene editing, has lately gained attention. It is composed of a nuclease (e.g., Cas9 and Cpf1) and a single guide RNA (sgRNA); the sgRNA is complementary to the target site and binds to the nuclease, directing the ribonuclear protein complex to the particular target site. CRISPR leads to either indel mutations or base alterations (i.e., A to $\mathrm{G}$ or C to T) at the target location, depending on the technique employed [105]. It is possible to carry out genome editing for a single gene or several genes using one or more sgRNAs. The study led by Sánchez-León et al. used CRISPR/Cas9 genome editing to successfully modify the majority of the $\alpha$-gliadin genes (up to 35) in wheat, reducing the expression of gluten proteins by as much as $85 \%$ [97]. Additionally, in the recent study conducted by Jouanin et al., CRISPR/Cas9 successfully modified $\alpha$-gliadin genes, and these researchers went on to demonstrate that the technique could be used to modify $\gamma$-gliadin genes in wheat [98]. When compared to the other methods described above, genome editing is the most recent, and its potential for altering gluten protein expression has not yet been thoroughly explored. In addition to indel-inducing CRISPR/Cas9 mutations, as shown by Sánchez-León et al., different kinds of base editors may be used to repair gluten proteins that are essential in end-use quality control yet include wheat sensitivity-related epitopes, as recently reviewed $[97,105,106]$. The versatility of genome editing took a big step forward recently with the development of prime editing, which can engineer all 12 forms of base substitutions, insertions ( 1 to $\geq 44 \mathrm{bp}$ ), deletions ( 1 to $\geq 80 \mathrm{bp}$ ), and combinations of the different types of alterations in a predetermined target site [107]. Through the use of multiplex editing, researchers may quickly and easily alter various gluten gene families and subtypes in a high throughput way. Finally, the various modification of CRISPR techniques may also be helpful in improving the end-use quality controlling function of those gluten members that are devoid of the CD epitopes. With these characteristics, as well as the relative simplicity with which genome-edited but transgene-free wheat plants may be obtained [108], it is reasonable to conclude that genome editing offers the greatest promise for eliminating or reducing the $\mathrm{CD}$ immunogenic epitopes for the simultaneous enhancement of wheat end-use and health-related features.

Unfortunately, stringent genetically modified organism (GMO) restrictions in many countries have slowed the creation of novel crop types via genome editing. This is especially true in areas that follow a process-based regulatory framework rather than a product-based regulatory framework, such as the European Union (EU), where authorizations for new varieties developed through genome editing techniques are subject to time- and costintensive verification procedures [109]. Recently, the European Court of Justice ruled that even if a product is devoid of transgenes, it must adhere to stringent GMO regulations [110]. At least 15 nations, including Brazil, India, China, and Australia, have implemented processbased rules, whereas 14 countries, including Canada, Argentina, and the Philippines, have adopted product-based regulations. Paraguay, Myanmar, Chile, and Vietnam are among the nations that still lack a formal regulatory framework. Argentina's adoption, which is more flexible since it takes current advances in genome editing into account, is one of the most intriguing elements of regulation. In accordance with existing law, genome-edited plants are usually classified as GMOs in the EU [111]. In the United States, the regulation of genetically modified (GM) crops is allowed on a case-by-case basis, as outlined in the organized framework for biotechnology control [112].

\section{Developing DNA-Free CRISPR-Edited Wheat to Minimize Regulatory Concerns (Ribonucleoprotein, RNP)}

When it comes to agriculture, CRISPR/Cas9 is extensively utilized to enhance characteristics by knocking out undesired genes or genes that result in undesirable phenotypes. However, this method often includes transgenic intermediates, raising regulatory issues 
and remaining unaccepted globally [113]. For public acceptance, gene removal or bypassing foreign elements to edit endogenous genes is a good choice [114]. Since CRISPR-mediated editing requires specific reagents, there are two primary methods to generate CRISPRedited DNA-free plants. In the vector-based method, a vector is delivered into wheat callus using Agrobacterium or particle bombardment. It subsequently integrates into the genome and expresses the encoded genome editing elements, allowing for targeted gene deletion. In $\mathrm{T}_{0}$ generation, targeted knockout wheat-containing foreign DNA is produced. Eventually, the foreign DNA may be separated via selfing and crossing. For example, using Agrobacterium-delivered CRISPR/Cas9, researchers were able to generate a TaQsd1 triple-knockout mutant. After crossing the mutant with wild-type wheat plants, transgenefree triple-recessive TaQsd1 mutants with prolonged seed dormancy were produced [115]. Similarly, it was found that the progeny of $\mathrm{T}_{0}$ plants produced a wheat mutant that was devoid of marker genes [116]. Occasionally, vectors are not always incorporated into the genome; instead, they may express their encoded genome editing elements transiently to knock off genes. The $T_{0}$ generation produces a specific gene-modified plantlet free of foreign DNA. For the first time, this method has been reported in wheat. Researchers used particle bombardment to introduce CRISPR/Cas9 elements into a wheat callus, and the plantlet was then regenerated without antibiotic selection. This transient expression-based CRISPR/Cas9 method resulted in homozygous, transgene-free mutants [117]. Furthermore, by transiently expressing cytosine base editors (CBEs) or adenine base editors (ABEs), transgene-free wheat with nucleotide changes has been created $[118,119]$. When using a non-vector approach, Cas9 and sgRNAs are transcribed in vitro and then delivered to immature wheat embryos via particle bombardment. Wheat plants with DNA-free genomes have been created. Although the editing efficiency was lower than with a vector-based approach, the specificity was greater [117]. In addition, nCas9-PBE mRNA and sgRNA were transcribed in vitro and injected into immature wheat embryos in this study. Using a DNA-free base editing technique, TaALS-P174 was able to confer resistance to herbicide nicosulfuron on wheat [120]. Furthermore, Cas9 may be produced in vitro and combined with sgRNA to form a Cas9/sg RNA ribonucleoprotein that is particle bombarded into immature wheat embryos. To create DNA-free modified wheat, we use an enzyme called ribonucleoprotein is used. The ribonucleoprotein rapidly cleaves the target region and degrades, resulting in DNA-free altered wheat [121]. GMO laws do not apply to the final CRISPR-edited DNA-free products, which are comparable to natural and artificial mutants. Due to the absence of integrated transgenes in CRISPR/Cas9 RNP mutant crop, their use in developing hypoimmunogenic wheat variety and commercialization should be more publicly acceptable.

\section{Conclusions}

An increasing pattern in the prevalence of celiac disease has been noticed in recent decades. Studies showed that increase in celiac awareness, development of highly sensitive celiac screening techniques in last decades definitely have a role. However, the exact reason for this increase is not known so far. Multiple other factors such as wheat breeding methods, use of nitrogen-based fertilizers, and use of the specific type of pesticides (glyphosate) have also been considered responsible for this increase. It is believed that a sole factor cannot be responsible for this increase; instead, all of these factors together possibly have a role. Recently, the use of increased amounts of $\mathrm{N}$ fertilizers has increased the amount of toxic gluten in wheat, which raises the risk of a celiac-specific immune response. Additionally, glyphosate exposure contributed to bacterial imbalances in the gut, which has been linked to $C D$. A wheat variety with a reduced amount of toxic components (low-immunogenic) could reduce this burden on the celiac-specific immune response. Genome editing through the CRISPR/Cas9 system can reduce the toxic effect and can produce a low-immunogenic wheat variety safe for such individuals. Even though the CRISPR/Cas9 technology has been used effectively to generate low-gluten wheat, its use is still limited. More efforts are 
needed to grasp, and make efficient use of, CRISPR/Cas9 for the development of a safer wheat variety.

Author Contributions: Conceptualization, S.M. and A.K.V.; literature review, S.M.; writing—original draft preparation, S.M.; writing-review and editing, S.M. and A.K.V.; final approval of the version to be published, S.M. and AKV. All authors have read and agreed to the published version of the manuscript.

Funding: This research received no external funding.

Institutional Review Board Statement: Not applicable.

Informed Consent Statement: Not applicable.

Conflicts of Interest: All authors declare no conflict of interest.

\section{References}

1. Verma, A.K.; Singh, A.; Gatti, S.; Lionetti, E.; Galeazzi, T.; Monachesi, C.; Franceschini, E.; Ahuja, V.; Catassi, C.; Makharia, G.K. Validation of a novel single-drop rapid human leukocyte antigen-DQ2/-DQ8 typing method to identify subjects susceptible to celiac disease. JGH Open 2018, 2, 311-316. [CrossRef] [PubMed]

2. King, J.A.; Jeong, J.; Underwood, F.E.; Quan, J.; Panaccione, N.; Windsor, J.W.; Coward, S.; Debruyn, J.; Ronksley, P.E.; Shaheen, A.-A.; et al. Incidence of Celiac Disease Is Increasing Over Time: A Systematic Review and Meta-analysis. Am. J. Gastroenterol. 2020, 115, 507-525. [CrossRef] [PubMed]

3. Mustalahti, K.; Catassi, C.; Reunanen, A.; Fabiani, E.; Heier, M.; McMillan, S.; Murray, L.; Metzger, M.H.; Gasparin, M.; Bravi, E.; et al. The prevalence of celiac disease in Europe: Results of a centralized, international mass screening project. Ann. Med. 2010, 42, 587-595. [CrossRef]

4. Ivarsson, A.; Myléus, A.; Norström, F.; Van Der Pals, M.; Rosén, A.; Högberg, L.; Danielsson, L.; Halvarsson, B.; Hammarroth, S.; Hernell, O.; et al. Prevalence of Childhood Celiac Disease and Changes in Infant Feeding. Pediatrics 2013, 131, e687-e694. [CrossRef] [PubMed]

5. Gatti, S.; Lionetti, E.; Balanzoni, L.; Verma, A.K.; Galeazzi, T.; Gesuita, R.; Scattolo, N.; Cinquetti, M.; Fasano, A.; Catassi, C.; et al. Increased Prevalence of Celiac Disease in School-age Children in Italy. Clin. Gastroenterol. Hepatol. 2019, 18, 596-603. [CrossRef]

6. Catassi, C.; Kryszak, D.; Bhatti, B.; Sturgeon, C.; Helzlsouer, K.; Clipp, S.L.; Gelfond, D.; Puppa, E.; Sferruzza, A.; Fasano, A. Natural history of celiac disease autoimmunity in a USA cohort followed since 1974. Ann. Med. 2010, 42, 530-538. [CrossRef]

7. Giersiepen, K.; Lelgemann, M.; Stuhldreher, N.; Ronfani, L.; Husby, S.; Koletzko, S.; Korponay-Szabó, I.R. Accuracy of Diagnostic Antibody Tests for Coeliac Disease in Children: Summary of an evidence report. J. Pediatr. Gastroenterol. Nutr. 2012, 54, $229-241$. [CrossRef]

8. Verma, A.K.; Gatti, S.; Lionetti, E.; Galeazzi, T.; Monachesi, C.; Franceschini, E.; Balanzoni, L.; Scattolo, N.; Cinquetti, M.; Catassi, C. Comparison of Diagnostic Performance of the IgA Anti-tTG Test vs IgA Anti-Native Gliadin Antibodies Test in Detection of Celiac Disease in the General Population. Clin. Gastroenterol. Hepatol. 2018, 16, 1997-1998. [CrossRef]

9. Bradauskiene, V.; Vaiciulyte-Funk, L.; Martinaitiene, D.; Andruskiene, J.; Verma, A.K.; Lima, J.P.M.; Serin, Y.; Catassi, C. Wheat consumption and prevalence of celiac disease: Correlation from a multilevel analysis. Crit. Rev. Food Sci. Nutr. $2021,1-15$. [CrossRef]

10. Cummins, A.G.; Roberts-Thomson, I.C. Prevalence of celiac disease in the Asia-Pacific region. J. Gastroenterol. Hepatol. 2009, 24, 1347-1351. [CrossRef]

11. Lionetti, E.; Catassi, C. Co-localization of gluten consumption and HLA-DQ2 and -DQ8 genotypes, a clue to the history of celiac disease. Dig. Liver Dis. 2014, 46, 1057-1063. [CrossRef] [PubMed]

12. Shiferaw, B.; Smale, M.; Braun, H.-J.; Duveiller, E.; Reynolds, M.; Muricho, G. Crops that feed the world 10. Past successes and future challenges to the role played by wheat in global food security. Food Secur. 2013, 5, 291-317. [CrossRef]

13. Hatfield, J.L.; Beres, B.L. Yield Gaps in Wheat: Path to Enhancing Productivity. Front. Plant Sci. 2019, 10. [CrossRef] [PubMed]

14. Boukid, F.; Vittadini, E.; Prandi, B.; Mattarozzi, M.; Marchini, M.; Sforza, S.; Sayar, R.; Seo, Y.W.; Yacoubi, I.; Mejri, M. Insights into a century of breeding of durum wheat in Tunisia: The properties of flours and starches isolated from landraces, old and modern genotypes. LWT 2018, 97, 743-751. [CrossRef]

15. De Santis, M.A.; Kosik, O.; Passmore, D.; Flagella, Z.; Shewry, P.R.; Lovegrove, A. Comparison of the dietary fibre composition of old and modern durum wheat (Triticum turgidum spp. durum) genotypes. Food Chem. 2017, 244, 304-310. [CrossRef]

16. De Santis, M.A.; Giuliani, M.M.; Giuzio, L.; De Vita, P.; Lovegrove, A.; Shewry, P.R.; Flagella, Z. Differences in gluten protein composition between old and modern durum wheat genotypes in relation to 20th century breeding in Italy. Eur. J. Agron. 2017, 87, 19-29. [CrossRef]

17. Maccaferri, M.; Sanguineti, M.C.; Corneti, S.; Ortega, J.L.A.; Ben Salem, M.; Bort, J.; DeAmbrogio, E.; Del Moral, L.F.G.; Demontis, A.; El-Ahmed, A.; et al. Quantitative Trait Loci for Grain Yield and Adaptation of Durum Wheat (Triticum durum Desf.) Across a Wide Range of Water Availability. Genetics 2008, 178, 489-511. [CrossRef] 
18. Collard, B.; Mackill, D.J. Marker-assisted selection: An approach for precision plant breeding in the twenty-first century. Philos. Trans. R. Soc. B Biol. Sci. 2007, 363, 557-572. [CrossRef]

19. De Vita, P.; Matteu, L.; Mastrangelo, A.M.; Di Fonzo, N.; Cattivelli, L. Effects of breeding activity on durum wheat traits breed in Italy during the 20th century. Ital. J. Agron. 2007, 2, 451-462. [CrossRef]

20. Raciti, C.; Doust, M.; Lombardo, G.; Boggini, G.; Pecetti, L. Characterization of durum wheat mediterranean germplasm for high and low molecular weight glutenin subunits in relation with quality. Eur. J. Agron. 2002, 19, 373-382. [CrossRef]

21. Rossini, F.; Provenzano, M.E.; Sestili, F.; Ruggeri, R. Synergistic Effect of Sulfur and Nitrogen in the Organic and Mineral Fertilization of Durum Wheat: Grain Yield and Quality Traits in the Mediterranean Environment. Agronomy 2018, 8, 189. [CrossRef]

22. Li, L.; Niu, Y.; Ruan, Y.; Depauw, R.M.; Singh, A.K.; Gan, Y. Agronomic Advancement in Tillage, Crop Rotation, Soil Health, and Genetic Gain in Durum Wheat Cultivation: A 17-Year Canadian Story. Agronomy 2018, 8, 193. [CrossRef]

23. Morris, C.E.; Sands, D.C. The breeder's dilemma-yield or nutrition? Nat. Biotechnol. 2006, 24, 1078-1080. [CrossRef]

24. Kucek, L.K.; Veenstra, L.D.; Amnuaycheewa, P.; Sorrells, M.E. A Grounded Guide to Gluten: How Modern Genotypes and Processing Impact Wheat Sensitivity. Compr. Rev. Food Sci. Food Saf. 2015, 14, 285-302. [CrossRef]

25. Scherf, K.A. Immunoreactive cereal proteins in wheat allergy, non-celiac gluten/wheat sensitivity (NCGS) and celiac disease. Curr. Opin. Food Sci. 2019, 25, 35-41. [CrossRef]

26. Yue, H.; Jiang, D.; Dai, T.; Qin, X.; Jing, Q.; Cao, W. Effect of nitrogen application rate on content of glutenin macropolymer and high molecular weight glutenin subunits in grains of two winter wheat cultivars. J. Cereal Sci. 2007, 45, 248-256. [CrossRef]

27. García-Molina, M.D.; Barro, F. Characterization of Changes in Gluten Proteins in Low-Gliadin Transgenic Wheat Lines in Response to Application of Different Nitrogen Regimes. Front. Plant Sci. 2017, 8. [CrossRef] [PubMed]

28. Daniel, C.; Triboi, E. Effects of Temperature and Nitrogen Nutrition on the Grain Composition of Winter Wheat: Effects on Gliadin Content and Composition. J. Cereal Sci. 2000, 32, 45-56. [CrossRef]

29. Ducsay, L.; Ložek, O. Effect of topdressing with nitrogen on the yield and quality of winter wheat grain. Plant Soil Environ. 2011, 50, 309-314. [CrossRef]

30. Tea, I.; Genter, T.; Naulet, N.; Boyer, V.; Lummerzheim, M.; Kleiber, D. Effect of Foliar Sulfur and Nitrogen Fertilization on Wheat Storage Protein Composition and Dough Mixing Properties. Cereal Chem. J. 2004, 81, 759-766. [CrossRef]

31. Varga, B.; Svečnjak, Z.; Jurković, Z.; Pospíšil, M. Quality responses of winter wheat cultivars to nitrogen and fungicide applications in Croatia. Acta Agron. Hung. 2007, 55, 37-48. [CrossRef]

32. Knapowski, T.; Ralcewicz, M.; Barczak, B.; Kozera, W. Effect of Nitrogen and Zinc Fertilizing on Bread-Making Quality of Spring Triticale Cultivated in Noteć Valley. Pol. J. Environ. Sustain. 2009, 18, 223-232.

33. Ralcewicz, M.; Knapowski, T.; Kozera, W.; Barczak, B. Technological value of spring wheat of zebra cultivar as related to the way of nitrogen and magnesium application. J. Cent. Eur. Agric. 2009, 10, $223-232$.

34. Zörb, C.; Grover, C.; Steinfurth, D.; Mühling, K.H. Quantitative proteome analysis of wheat gluten as influenced by N and S nutrition. Plant Soil 2009, 327, 225-234. [CrossRef]

35. Zecevic, V.; Knezevic, D.; Boskovic, J.; Milenkovic, S. Effect of nitrogen and ecological factors on quality of winter triticale cultivars. Genetika 2010, 42, 465-474. [CrossRef]

36. Fuertes-Mendizábal, T.; Aizpurua, A.; Moro, G.; Estavillo, J. Improving wheat breadmaking quality by splitting the N fertilizer rate. Eur. J. Agron. 2010, 33, 52-61. [CrossRef]

37. Wan, Y.; Shewry, P.R.; Hawkesford, M. A novel family of $\gamma$-gliadin genes are highly regulated by nitrogen supply in developing wheat grain. J. Exp. Bot. 2012, 64, 161-168. [CrossRef]

38. Fuertes-Mendizábal, T.; Torralba, J.G.; Arregui, L.M.; Gonzalez-Murua, C.; Moro, G.; Estavillo, J.M. Ammonium as sole N source improves grain quality in wheat. J. Sci. Food Agric. 2012, 93, 2162-2171. [CrossRef]

39. Wojtkowiak, K.; Stpie, A.; Taska, M.; Konopka, I.; Konopka, S. Impact of nitrogen fertilization on the yield and content of protein fractions in spring triticale grain. Afr. J. Agric. Res. 2013, 8, 3778-3783. [CrossRef]

40. Wan, Y.; Gritsch, C.S.; Hawkesford, M.; Shewry, P.R. Effects of nitrogen nutrition on the synthesis and deposition of the $\omega$-gliadins of wheat. Ann. Bot. 2013, 113, 607-615. [CrossRef]

41. Rodrighero, M.B.; Caires, E.; Lopes, R.B.; Zielinski, A.; Granato, D.; Demiate, I.M. Wheat technological quality as affected by nitrogen fertilization under a no-till system. Acta Sci. Technol. 2015, 37, 175. [CrossRef]

42. Klikocka, H.; Cybulska, M.; Barczak, B.; Narolski, B.; Szostak, B.; Kobiałka, A.; Nowak, A.; Wójcik, E. The effect of sulphur and nitrogen fertilization on grain yield and technological quality of spring wheat. Plant Soil Environ. 2016, 62, 230-236. [CrossRef]

43. Galieni, A.; Stagnari, F.; Visioli, G.; Marmiroli, N.; Speca, S.; Angelozzi, G.; D’Egidio, S.; Pisante, M. Nitrogen fertilisation of durum wheat: A case of study in Mediterranean area during transition to conservation agriculture. Ital. J. Agron. 2015, 11, 12. [CrossRef]

44. Zhen, S.; Zhou, J.; Deng, X.; Zhu, G.; Cao, H.; Wang, Z.; Yan, Y. Metabolite profiling of the response to high-nitrogen fertilizer during grain development of bread wheat (Triticum aestivum L.). J. Cereal Sci. 2016, 69, 85-94. [CrossRef]

45. Xue, C.; Erley, G.S.A.; Rücker, S.; Koehler, P.; Obenauf, U.; Mühling, K.H. Late nitrogen application increased protein concentration but not baking quality of wheat. J. Plant Nutr. Soil Sci. 2016, 179, 591-601. [CrossRef] 
46. Zheng, T.; Qi, P.-F.; Cao, Y.-L.; Han, Y.-N.; Ma, H.-L.; Guo, Z.-R.; Wang, Y.; Qiao, Y.-Y.; Hua, S.-Y.; Yu, H.-Y.; et al. Mechanisms of wheat (Triticum aestivum) grain storage proteins in response to nitrogen application and its impacts on processing quality. Sci. Rep. 2018, 8, 11928. [CrossRef]

47. Litke, L.; Gaile, Z. Effect of nitrogen fertilization on winter wheat yield and yield quality. Agron. Res. 2018, 16, 500. [CrossRef]

48. Cho, S.-W.; Kang, C.-S.; Kang, T.-G.; Cho, K.-M.; Park, C.S. Influence of different nitrogen application on flour properties, gluten properties by HPLC and end-use quality of Korean wheat. J. Integr. Agric. 2018, 17, 982-993. [CrossRef]

49. Dubois, B.; Bertin, P.; Hautier, L.; Muhovski, Y.; Escarnot, E.; Mingeot, D. Genetic and environmental factors affecting the expression of $\alpha$-gliadin canonical epitopes involved in celiac disease in a wide collection of spelt (Triticum aestivum ssp. spelta) cultivars and landraces. BMC Plant Biol. 2018, 18, 262. [CrossRef]

50. Guardia, G.; Sanz-Cobena, A.; Sanchez-Martin, L.; Fuertes-Mendizábal, T.; Gonzalez-Murua, C.; Alvarez, J.M.A.; Chadwick, D.; Vallejo, A. Urea-based fertilization strategies to reduce yield-scaled $\mathrm{N}$ oxides and enhance bread-making quality in a rainfed Mediterranean wheat crop. Agric. Ecosyst. Environ. 2018, 265, 421-431. [CrossRef]

51. Klikocka, H.; Marks, M.; Marx, M. Sulphur and Nitrogen Fertilization as a Potential Means of Agronomic Biofortification to Improve the Content and Uptake of Microelements in Spring Wheat Grain DM. J. Chem. 2018, 2018, 9326820. [CrossRef]

52. Xue, C.; Matros, A.; Mock, H.-P.; Mühling, K.H. Protein Composition and Baking Quality of Wheat Flour as Affected by Split Nitrogen Application. Front. Plant Sci. 2019, 10, 642. [CrossRef]

53. Eser, A.; Kassai, K.; Kato, H.; Kunos, V.; Tarnava, A.; Jolánkai, M. Impact of nitrogen topdressing on the quality parameters of winter wheat (Triticum aestivum L.) yield. Acta Aliment. 2020, 49, 244-253. [CrossRef]

54. Zhen, S.; Deng, X.; Xu, X.; Liu, N.; Zhu, D.; Wang, Z.; Yan, Y. Effect of high-nitrogen fertilizer on gliadin and glutenin subproteomes during kernel development in wheat (Triticum aestivum L.). Crop. J. 2020, 8, 38-52. [CrossRef]

55. Song, L.; Li, L.; Zhao, L.; Liu, Z.; Li, X. Effects of Nitrogen Application in the Wheat Booting Stage on Glutenin Polymerization and Structural-Thermal Properties of Gluten with Variations in HMW-GS at the Glu-D1 Locus. Foods 2020, 9, 353. [CrossRef]

56. Pepo, P.; Sipos, P.; Gyóri, Z. Effects of fertilizer application on the baking quality of winter wheat varieties in a long term experiment under continental climatic conditions in Hungary. Cereal Res. Commun. 2005, 33, 825-832. [CrossRef]

57. Turhan, D.; Güngördü, A.; Ozmen, M. Developmental and lethal effects of glyphosate and a glyphosate-based product on Xenopus laevis embryos and tadpoles. Bull. Environ. Contam. Toxicol. 2020, 104, 173-179. [CrossRef]

58. Mertens, M.; Höss, S.; Neumann, G.; Afzal, J.; Reichenbecher, W. Glyphosate, a chelating agent—relevant for ecological risk assessment? Environ. Sci. Pollut. Res. 2018, 25, 5298-5317. [CrossRef]

59. Van Bruggen, A.H.C.; He, M.M.; Shin, K.; Mai, V.; Jeong, K.C.; Finckh, M.R.; Morris, J.G., Jr. Environmental and health effects of the herbicide glyphosate. Sci. Total Environ. 2018, 616, 255-268. [CrossRef] [PubMed]

60. Thursby, E.; Juge, N. Introduction to the human gut microbiota. Biochem. J. 2017, 474, 1823-1836. [CrossRef] [PubMed]

61. Blot, N.; Veillat, L.; Rouzé, R.; Delatte, H. Glyphosate, but not its metabolite AMPA, alters the honeybee gut microbiota. PLoS ONE 2019, 14, e0215466. [CrossRef] [PubMed]

62. Maddalon, A.; Galbiati, V.; Colosio, C.; Mandić-Rajčević, S.; Corsini, E. Glyphosate-based herbicides: Evidence of immuneendocrine alteration. Toxicology 2021, 459, 152851. [CrossRef] [PubMed]

63. Gorbach, S. Microbiology of the Gastrointestinal Tract. In Medical Microbiology, 4th ed.; Baron, S., Ed.; University of Texas Medical Branch: Galveston, TX, USA, 1996.

64. Sanz, Y.; De Palma, G.; Laparra, M. Unraveling the Ties between Celiac Disease and Intestinal Microbiota. Int. Rev. Immunol. 2011, 30, 207-218. [CrossRef] [PubMed]

65. Di Cagno, R.; De Angelis, M.; De Pasquale, I.; Ndagijimana, M.; Vernocchi, P.; Ricciuti, P.; Gagliardi, F.; Laghi, L.; Crecchio, C.; Guerzoni, M.E.; et al. Duodenal and faecal microbiota of celiac children: Molecular, phenotype and metabolome characterization. BMC Microbiol. 2011, 11, 219. [CrossRef]

66. Collado, M.C.; Calabuig, M.S.Y. Differences between the Faecal Microbiota of Coeliac Infants and Healthy Controls. Curr. Issues Intest Microbiol. 2007, 8, 9-14.

67. Francavilla, R.; De Angelis, M.; Rizzello, C.G.; Cavallo, N.; Bello, F.D.; Gobbetti, M. Selected Probiotic Lactobacilli Have the Capacity To Hydrolyze Gluten Peptides during Simulated Gastrointestinal Digestion. Appl. Environ. Microbiol. 2017, 83, e00376-17. [CrossRef]

68. Greco, L.; Gobbetti, M.; Auricchio, R.; Di Mase, R.; Landolfo, F.; Paparo, F.; Di Cagno, R.; De Angelis, M.; Rizzello, C.G.; Cassone, A.; et al. Safety for Patients With Celiac Disease of Baked Goods Made of Wheat Flour Hydrolyzed During Food Processing. Clin. Gastroenterol. Hepatol. 2011, 9, 24-29. [CrossRef]

69. Tang, Q.; Tang, J.; Ren, X.; Li, C. Glyphosate exposure induces inflammatory responses in the small intestine and alters gut microbial composition in rats. Environ. Pollut. 2020, 261, 114129. [CrossRef]

70. Mao, Q.; Manservisi, F.; Panzacchi, S.; Mandrioli, D.; Menghetti, I.; Vornoli, A.; Bua, L.; Falcioni, L.; Lesseur, C.; Chen, J.; et al. The Ramazzini Institute 13-week pilot study on glyphosate and Roundup administered at human-equivalent dose to Sprague Dawley rats: Effects on the microbiome. Environ. Health 2018, 17, 50. [CrossRef]

71. Lerner, A.; Arleevskaya, M.; Schmiedl, A.; Matthias, T. Microbes and Viruses Are Bugging the Gut in Celiac Disease. Are They Friends or Foes? Front. Microbiol. 2017, 8, 1392. [CrossRef] 
72. Ou, G.; Hedberg, M.; Hörstedt, P.; Baranov, V.; Forsberg, G.; Drobni, M.; Sandström, O.; Wai, S.N.; Johansson, I.; Hammarström, M.-L.; et al. Proximal Small Intestinal Microbiota and Identification of Rod-Shaped Bacteria Associated With Childhood Celiac Disease. Am. J. Gastroenterol. 2009, 104, 3058-3067. [CrossRef]

73. Zamakhchari, M.; Wei, G.; Dewhirst, F.; Lee, J.; Schuppan, D.; Oppenheim, F.G.; Helmerhorst, E.J. Identification of Rothia Bacteria as Gluten-Degrading Natural Colonizers of the Upper Gastro-Intestinal Tract. PLoS ONE 2011, 6, e24455. [CrossRef] [PubMed]

74. Park, C.H.; Han, D.S.; Oh, Y.-H.; Lee, A.-R.; Lee, Y.-R.; Eun, C.S. Role of Fusobacteria in the serrated pathway of colorectal carcinogenesis. Sci. Rep. 2016, 6, 25271. [CrossRef]

75. Kittana, H.; Gomes-Neto, J.C.; Heck, K.; Geis, A.L.; Muñoz, R.R.S.; Cody, L.A.; Schmaltz, R.J.; Bindels, L.B.; Sinha, R.; Hostetter, J.; et al. Commensal Escherichia coli Strains Can Promote Intestinal Inflammation via Differential Interleukin-6 Production. Front. Immunol. 2018, 9, 2318. [CrossRef] [PubMed]

76. Koliada, A.; Syzenko, G.; Moseiko, V.; Budovska, L.; Puchkov, K.; Perederiy, V.; Gavalko, Y.; Dorofeyev, A.; Romanenko, M.; Tkach, S.; et al. Association between body mass index and Firmicutes/Bacteroidetes ratio in an adult Ukrainian population. BMC Microbiol. 2017, 17, 120. [CrossRef] [PubMed]

77. Rustgi, S.; Shewry, P.; Brouns, F.; Deleu, L.J.; Delcour, J.A. Wheat Seed Proteins: Factors Influencing Their Content, Composition, and Technological Properties, and Strategies to Reduce Adverse Reactions. Compr. Rev. Food Sci. Food Saf. 2019, 18, 1751-1769. [CrossRef]

78. Altenbach, S.B.; Tanaka, C.K.; Allen, P.V. Quantitative proteomic analysis of wheat grain proteins reveals differential effects of silencing of omega-5 gliadin genes in transgenic lines. J. Cereal Sci. 2014, 59, 118-125. [CrossRef]

79. Altenbach, S.B.; Tanaka, C.K.; Seabourn, B.W. Silencing of omega-5 gliadins in transgenic wheat eliminates a major source of environmental variability and improves dough mixing properties of flour. BMC Plant Biol. 2014, 14, 393. [CrossRef]

80. Blechl, A.; Beecher, B.; Vensel, W.; Tanaka, C.; Altenbach, S. RNA interference targeting rye secalins alters flour protein composition in a wheat variety carrying a 1BL.1RS translocation. J. Cereal Sci. 2016, 68, 172-180. [CrossRef]

81. Barro, F.; Iehisa, J.C.M.; Gimenez, M.J.; García-Molina, M.D.; Ozuna, C.V.; Comino, I.; Sousa, C.; Gil Humanes, J. Targeting of prolamins by RNAi in bread wheat: Effectiveness of seven silencing-fragment combinations for obtaining lines devoid of coeliac disease epitopes from highly immunogenic gliadins. Plant Biotechnol. J. 2015, 14, 986-996. [CrossRef]

82. Altenbach, S.B.; Allen, P.V. Transformation of the US bread wheat 'Butte 86 ' and silencing of omega-5 gliadin genes. GM Crop. 2011, 2, 66-73. [CrossRef] [PubMed]

83. Altenbach, S.B.; Tanaka, C.K.; Pineau, F.; Lupi, R.; Drouet, M.; Beaudouin, E.; Morisset, M.; Denery-Papini, S. Assessment of the Allergenic Potential of Transgenic Wheat (Triticum aestivum) with Reduced Levels of $\omega 5$-Gliadins, the Major Sensitizing Allergen in Wheat-Dependent Exercise-Induced Anaphylaxis. J. Agric. Food Chem. 2015, 63, 9323-9332. [CrossRef] [PubMed]

84. Becker, D.; Wieser, H.; Koehler, P.; Folck, A.; Mühling, K.H.; Zörb, C. Protein composition and techno-functional properties of transgenic wheat with reduced $\alpha$-gliadin content obtained by RNA interference. J. Appl. Bot. Food Quality 2012, 85, 23-33.

85. Gil-Humanes, J.; Piston, F.; Tollefsen, S.; Sollid, L.M.; Barro, F. Effective shutdown in the expression of celiac disease-related wheat gliadin T-cell epitopes by RNA interference. Proc. Natl. Acad. Sci. USA 2010, 107, 17023-17028. [CrossRef] [PubMed]

86. Gil-Humanes, J.; Piston, F.; Gimenez, M.J.; Martín, A.; Barro, F. The Introgression of RNAi Silencing of $\gamma$-Gliadins into Commercial Lines of Bread Wheat Changes the Mixing and Technological Properties of the Dough. PLoS ONE 2012, 7, e45937. [CrossRef]

87. Gil-Humanes, J.; Pistón, F.; Barro, F.; Rosell, C.M. The Shutdown of Celiac Disease-Related Gliadin Epitopes in Bread Wheat by RNAi Provides Flours with Increased Stability and Better Tolerance to Over-Mixing. PLoS ONE 2014, 9, e91931. [CrossRef]

88. Gil-Humanes, J.; Pistón, F.; Altamirano-Fortoul, R.; Real, A.; Comino, I.; Sousa, C.; Rosell, C.M.; Barro, F. Reduced-Gliadin Wheat Bread: An Alternative to the Gluten-Free Diet for Consumers Suffering Gluten-Related Pathologies. PLoS ONE 2014, 9, e90898. [CrossRef] [PubMed]

89. Gil Humanes, J.; Piston, F.; Hernando, A.; Alvarez, J.B.; Shewry, P.R.; Barro, F. Silencing of $\gamma$-gliadins by RNA interference (RNAi) in bread wheat. J. Cereal Sci. 2008, 48, 565-568. [CrossRef]

90. Pistón, F.; Gil Humanes, J.; Rodríguez-Quijano, M.; Barro, F. Down-Regulating $\gamma$-Gliadins in Bread Wheat Leads to Non-Specific Increases in Other Gluten Proteins and Has No Major Effect on Dough Gluten Strength. PLoS ONE 2011, 6, e24754. [CrossRef]

91. Osorio, C.E.; Wen, N.; Mejías, J.; Liu, B.; Reinbothe, S.; Von Wettstein, D.; Rustgi, S. Development of wheat genotypes expressing a glutamine-specific endoprotease from barley and a prolyl endopeptidase from Flavobacterium meningosepticum or Pyrococcus furiosus as a potential remedy to celiac disease. Funct. Integr. Genom. 2018, 19, 123-136. [CrossRef]

92. Li, D.; Jin, H.; Zhang, K.; Wang, Z.; Wang, F.; Zhao, Y.; Huo, N.; Liu, X.; Gu, Y.Q.; Wang, D.; et al. Analysis of the Gli-D2 locus identifies a genetic target for simultaneously improving the breadmaking and health-related traits of common wheat. Plant $J$. 2018, 95, 414-426. [CrossRef] [PubMed]

93. Wang, D.-W.; Li, D.; Wang, J.; Zhao, Y.; Wang, Z.; Yue, G.; Liu, X.; Qin, H.; Zhang, K.; Dong, L.; et al. Genome-wide analysis of complex wheat gliadins, the dominant carriers of celiac disease epitopes. Sci. Rep. 2017, 7, 44609. [CrossRef]

94. Camerlengo, F.; Sestili, F.; Silvestri, M.; Colaprico, G.; Margiotta, B.; Ruggeri, R.; Lupi, R.; Masci, S.; Lafiandra, D. Production and molecular characterization of bread wheat lines with reduced amount of $\alpha$-type gliadins. BMC Plant Biol. 2017, 17, 248. [CrossRef] [PubMed]

95. Waga, J.; Skoczowski, A. Development and characteristics of $\omega$-gliadin-free wheat genotypes. Euphytica 2013, 195, 105-116. [CrossRef] 
96. Waga, J.; Zientarski, J.; Szaleniec, M.; Obtułowicz, K.; Dyga, W.; Skoczowski, A. Null Alleles in Gliadin Coding Loci and Wheat Allergenic Properties. Am. J. Plant Sci. 2013, 4, 160-168. [CrossRef]

97. León, S.S.; Gil Humanes, J.; Ozuna, C.V.; Gimenez, M.J.; Sousa, C.; Voytas, D.; Barro, F. Low-gluten, nontransgenic wheat engineered with CRISPR/Cas9. Plant Biotechnol. J. 2017, 16, 902-910. [CrossRef]

98. Jouanin, A.; Schaart, J.G.; Boyd, L.A.; Cockram, J.; Leigh, F.; Bates, R.; Wallington, E.J.; Visser, R.G.F.; Smulders, M.J.M. Outlook for coeliac disease patients: Towards bread wheat with hypoimmunogenic gluten by gene editing of $\alpha$ - and $\gamma$-gliadin gene families. BMC Plant Biol. 2019, 19, 333. [CrossRef] [PubMed]

99. Zörb, C.; Becker, D.; Hasler, M.; Muehling, K.H.; Gödde, V.; Niehaus, K.; Geilfus, C.-M. Silencing of the sulfur rich $\alpha$-gliadin storage protein family in wheat grains (Triticum aestivum L.) causes no unintended side-effects on other metabolites. Front. Plant Sci. 2013, 4, 369. [CrossRef] [PubMed]

100. Altenbach, S.B.; Chang, H.-C.; Simon-Buss, A.; Mohr, T.; Huo, N.; Gu, Y.Q. Exploiting the reference genome sequence of hexaploid wheat: A proteomic study of flour proteins from the cultivar Chinese Spring. Funct. Integr. Genom. 2020, 20, 1-16. [CrossRef]

101. Altenbach, S.B.; Chang, H.-C.; Yu, X.B.; Seabourn, B.W.; Green, P.H.; Alaedini, A. Elimination of Omega-1,2 Gliadins From Bread Wheat (Triticum aestivum) Flour: Effects on Immunogenic Potential and End-Use Quality. Front. Plant Sci. 2019, 10. [CrossRef]

102. Chai, J.-F.; Wang, H.-B.; Ma, X.-Y.; Zhang, C.-M.; Dong, F.-S. Effect of $\omega$-Secalin Gene Silencing on Processing Quality of Wheat 1B/1R Translocation Line. Acta Agron. Sin. 2016, 42. [CrossRef]

103. Chai, J.-F.; Zhang, C.-M.; Ma, X.-Y.; Wang, H.-B. Molecular identification of $\omega$-secalin gene expression activity in a wheat $1 \mathrm{~B} / 1 \mathrm{R}$ translocation cultivar. J. Integr. Agric. 2016, 15, 2712-2718. [CrossRef]

104. García-Molina, M.D.; Giménez, M.J.; León, S.S.; Barro, F. Gluten Free Wheat: Are We There? Nutrients 2019, 11, 487. [CrossRef] [PubMed]

105. Chen, K.; Wang, Y.; Zhang, R.; Zhang, H.; Gao, C. CRISPR/Cas Genome Editing and Precision Plant Breeding in Agriculture. Annu. Rev. Plant Biol. 2019, 70, 667-697. [CrossRef] [PubMed]

106. Mishra, R.; Joshi, R.K.; Zhao, K. Base editing in crops: Current advances, limitations and future implications. Plant Biotechnol. J. 2019, 18, 20-31. [CrossRef]

107. Anzalone, A.V.; Randolph, P.B.; Davis, J.R.; Sousa, A.A.; Koblan, L.W.; Levy, J.M.; Chen, P.J.; Wilson, C.; Newby, G.A.; Raguram, A.; et al. Search-and-replace genome editing without double-strand breaks or donor DNA. Nature 2019, 576, 149-157. [CrossRef] [PubMed]

108. Verma, A.K.; Mandal, S.; Tiwari, A.; Monachesi, C.; Catassi, G.N.; Srivastava, A.; Gatti, S.; Lionetti, E.; Catassi, C. Current Status and Perspectives on the Application of CRISPR/Cas9 Gene-Editing System to Develop a Low-Gluten, Non-Transgenic Wheat Variety. Foods 2021, 10, 2351. [CrossRef]

109. Ishii, T.; Araki, M. A future scenario of the global regulatory landscape regarding genome-edited crops. GM Crop. Food 2017, 8 , 44-56. [CrossRef]

110. Wolt, J.D.; Wang, K.; Yang, B. The Regulatory Status of Genome-edited Crops. Plant Biotechnol. J. 2015, 14, 510-518. [CrossRef]

111. Callaway, E. CRISPR plants now subject to tough GM laws in European Union. Nature 2018, 560, 16. [CrossRef]

112. Sprink, T.; Eriksson, D.; Schiemann, J.; Hartung, F. Regulatory hurdles for genome editing: Process- vs. product-based approaches in different regulatory contexts. Plant Cell Rep. 2016, 35, 1493-1506. [CrossRef] [PubMed]

113. Zhang, Y.; Pribil, M.; Palmgren, M.; Gao, C. A CRISPR way for accelerating improvement of food crops. Nat. Food 2020, 1, 200-205. [CrossRef]

114. He, Y.; Zhao, Y. Technological breakthroughs in generating transgene-free and genetically stable CRISPR-edited plants. aBIOTECH 2019, 1, 88-96. [CrossRef]

115. Abe, F.; Haque, E.; Hisano, H.; Tanaka, T.; Kamiya, Y.; Mikami, M.; Kawaura, K.; Endo, M.; Onishi, K.; Hayashi, T.; et al. Genome-Edited Triple-Recessive Mutation Alters Seed Dormancy in Wheat. Cell Rep. 2019, 28, 1362-1369.e4. [CrossRef]

116. Wang, K.; Liu, H.; Du, L.; Ye, X. Generation of marker-free transgenic hexaploid wheat via an Agrobacterium-mediated co-transformation strategy in commercial Chinese wheat varieties. Plant Biotechnol. J. 2016, 15, 614-623. [CrossRef] [PubMed]

117. Zhang, Y.; Liang, Z.; Zong, Y.; Wang, Y.; Liu, J.; Chen, K.; Qiu, J.-L.; Gao, C. Efficient and transgene-free genome editing in wheat through transient expression of CRISPR/Cas9 DNA or RNA. Nat. Commun. 2016, 7, 12617. [CrossRef]

118. Zong, Y.; Wang, Y.; Li, C.; Zhang, R.; Chen, K.; Ran, Y.; Qiu, J.-L.; Wang, D.; Gao, C. Precise base editing in rice, wheat and maize with a Cas9-cytidine deaminase fusion. Nat. Biotechnol. 2017, 35, 438-440. [CrossRef] [PubMed]

119. Li, C.; Zong, Y.; Wang, Y.; Jin, S.; Zhang, D.; Song, Q.; Zhang, R.; Gao, C. Expanded base editing in rice and wheat using a Cas9-adenosine deaminase fusion. Genome Biol. 2018, 19, 59. [CrossRef] [PubMed]

120. Zhang, R.; Liu, J.; Chai, Z.; Chen, S.; Bai, Y.; Zong, Y.; Chen, K.; Li, J.; Jiang, L.; Gao, C. Generation of herbicide tolerance traits and a new selectable marker in wheat using base editing. Nat. Plants 2019, 5, 480-485. [CrossRef]

121. Liang, Z.; Chen, K.; Li, T.; Zhang, Y.; Wang, Y.; Zhao, Q.; Liu, J.; Zhang, H.; Liu, C.; Ran, Y.; et al. Efficient DNA-free genome editing of bread wheat using CRISPR/Cas9 ribonucleoprotein complexes. Nat. Commun. 2017, 8, 14261. [CrossRef] 